
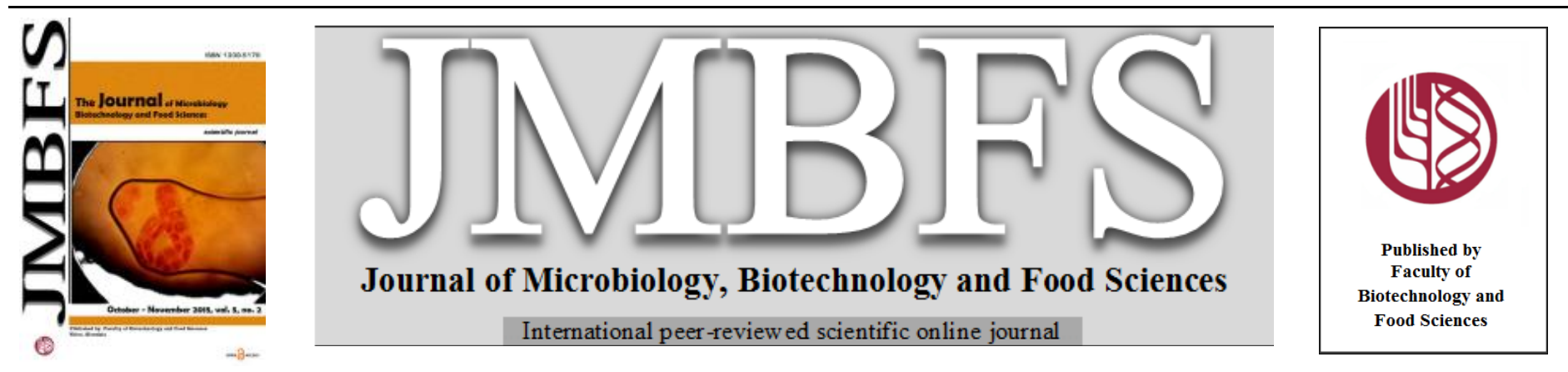

\title{
ASPECTS OF EGGS QUALITY PROVIDED FROM FREE RANGE AND CONVENTIONAL SYSTEMS
}

\section{Lucia Iuliana Nistor (Cotfas)*', Aida Albu ${ }^{1}$, Andreea Cătălina Nistor ${ }^{1}$, Marius Giorgi Usturoi ${ }^{1}$}

Address(es): Phd Lucia Iuliana Nistor(Cotfas),

${ }^{1}$ University of Agricultural Sciences and Veterinary Medicine, Faculty of Animal Science, Department Management of Animal Production, 8, Mihail Sadoveanu Alley, 700489, Iaşi, Romania, phone number: 0232267.504.

*Corresponding author: iulia_cotfas@yahoo.com

doi: 10.15414/jmbfs.2015.5.2.186-189

\section{ARTICLE INFO}

Received 16. 5. 2015

Revised 15. 7. 2015

Accepted 12. 8. 2015

Published 1. 10. 2015

Regular article OPEN $\partial_{\text {ACCESS }}$

\begin{abstract}
Egg, is a complete food that plays a critical role in daily nutrition, irrespective of the trade vessels has been obtained. The aim of the current paper is to compare the chemical indicators and the microbial load of eggs from two operating systems for laying hens (EU approved battery and free range). Were taken in study 120 eggs from those two systems of rearing which 90 eggs we are making chemical analysis of albumen, yolk, and whole egg, and 30 eggs were stored in refrigerating conditions for microbiological indicators. Egg obtained from free range system have a slightly higher content of protein from albumen (10.36 $\pm 0.12 \%$ vs. 9.98 $\pm 0.03 \%)$ compared with conventional system, and a higher content of lipids of yolk with $2.24 \%$. We determined the eggshell TNGMA by rapid method Tempo TVC and by content of egg with decimal dilutions and inoculation with Plate Count Agar. Following these determinations TNGMA on the eggshell recorded the highest level of contamination in eggs obtained from free range system 5.01 log cfu/eggshell, and the situation was available for TNGMA of egg contents $2.76 \pm 0,58 \mathrm{cfu} / \mathrm{g}$. Rearing in freedom of laying hens (free range) caused a qualitative improvement of dry components of both the egg components (yolk and albumen) but also the quantitative one, and eggs obtained has a high nutritional value, but hygiene and biosecurity are very important concepts, not only on the health of laying hens, but also in terms of consumer health, and eggs from alternative systems are high microbiological load than eggs from conventional systems.
\end{abstract}

Keywords: Bacterial contamination, chemical indicators, conventional, free range, egg

\section{INTRODUCTION}

Eggs represent a complete food that has a critical role in daily nutrition, regardless of the operating system that was obtained, being one of the most versatile food sources (Matt $\boldsymbol{e t}$ al., 2009). Increased desire of today's consumers for products produced in extensive production systems, such as free range, due to concerns about their food safety and animal welfare has led to an expansion of alternative operating systems laying hens (Anderson, 2009). These alternative farming systems have become priority from 1 January 2012, when conventional batteries were banned and replaced with approved batteries which respected notion of welfare, but also systems that allow free range hens access to the outside environment (Vučemilo et al., 2010), which brings welfare pluses, but bring and minuses in terms of food safety. Free range egg is produced in poultry farms practicing a growing technology that birds have access to outdoor paddock in their specific living environment, where they can show all instincts ethological and physiological (Usturoi, 2004). Biosecurity and hygiene is particularly important concepts, not only on the health of laying hens, and in terms of consumer health. In alternative systems, where the birds have access to the outside, is acumulate a significant amount of dust, particularly in the permanent sheets with the consequence of a microbial contamination of the air. In alternative systems have a contamination of shell eggs produced generally by aerobic bacteria (Anderson, 2009). Messens et al. (2007) showed that the microclimate high microbial load, increase the number of microorganisms on the mineral shell, which leads to their penetration into the egg. In terms of quality eggs obtained from hens kept in alternative systems specialist opinions are divided. For example, Minelli (2007) states that eggs from the European Union agreed systems have a lower resistance to break both the shell and components, while Hidalgo et al., 2008 ) reported a higher weight and resistance to breakage better than those obtained in conventional systems. In this study, the main objective was to determine the quality of eggs from two breeding systems (EU approved battery and free range), expressed by the results both mineral shell and the egg contents .

\section{MATERIAL AND METHODS}

The material studied was the 120 eggs from Lohmann Brown hens free range system operated (batch A) and the EU approved batteries (batch B). They were distributed 90 eggs, for chemical analysis, and 30 eggs for microbiological analysis. Hens in both batches were fed with mixed fodder, obtained after the same recipe, particularly, the free range system had access to the paddock for the hall outside.

\section{Experimental scheme research}

\begin{tabular}{|c|c|c|}
\hline \multirow{2}{*}{ Specifications } & \multicolumn{2}{|c|}{ Batches of experience } \\
\hline & Batch A & Batch B \\
\hline Hybrid Used & \multicolumn{2}{|c|}{ Lohmann Brown } \\
\hline Operated system & Free - range & EU approved batery \\
\hline Insured surface & $\begin{array}{l}\text { In hall }=9 \mathrm{birds} / \mathrm{m}^{2} \\
\text { In padock }=4 \mathrm{~m}^{2} / \mathrm{bird}\end{array}$ & $750 \mathrm{~cm}^{2} /$ birds \\
\hline Studied material & $\begin{array}{l}90 \text { eggs for chemical } \\
\text { analysis }\end{array}$ & $\begin{array}{c}30 \text { eggs for } \\
\text { microbiological } \\
\text { anaysis }\end{array}$ \\
\hline \multirow{6}{*}{ Follow indicators } & Water (\%) & \multirow{3}{*}{ TNGMA eggshell } \\
\hline & Dry matter $(\%)$ & \\
\hline & Proteins $(\%)$ & \\
\hline & Lipids (\%) & \multirow{3}{*}{ TNGMA content } \\
\hline & Ash (\%) & \\
\hline & Nitrogen free extract $(\%)$ & \\
\hline
\end{tabular}

\section{Chemical analysis}

Chemical analysis were performed on the components of edible egg (white, yolk and mix respectively), in order to quantify values for the water content in the dry substances; was also determined the proportion of ash, protein, fat and nitrogen free extract on dry. For chemical analysis, mineral shell after breaking was 
remove for each egg, yolk was separated whites (60 samples), after which the chemical composition have been established for each of the two components. The rest of the sample (30 eggs) albumen and yolk of each egg mixture obtained in natural proportion (mix) that were performed the same type of analysis. This analysis were performed in accordance with applicable standards (AOAC, 1990).

\section{Microbiological analysis}

The 30 eggs were subjected to microbiological analysis, that were stored under refrigeration $\left(4^{\circ} \mathrm{C}\right.$, relative humidity $\left.=90 \%\right)$ by determining the microbiological indicators carried out every 7 days throughout the period of validity of 21 days To determine TNGMA was used decimal dilution method, which involves weighing $10 \mathrm{~g}$ of the product to be analyzed, the was homogenization with $90 \mathrm{~mL}$ sterilized diluent and titration of the sample to give the first dilution $\left(10^{-1}\right.$ or 1/10); further decimal dilutions are carried out in succession. From each dilution determined for each $1 \mathrm{~mL}$ seed is distributed in the center of two Petri plates . In order to achieve inoculated pour plate culture medium $15 \mathrm{~mL}$ melted and cooled to $45-50^{\circ} \mathrm{C}$, then mix the inoculum with Plate Count agar, by moving forward and backward, right, left. After the medium has solidified, the Petri dishes are placed in thermostat, with the cover down at $30^{\circ} \mathrm{C}$. After 48 hours the thermostat, are removed and the Petri dishes are developed colonies (between 10-300 colonies). The alternative method used to determine the mineral shell is TNGMA the TEMPO TVC is an automatic test system using rapid analysis; Tempo allows enumeration of mesophilic aerobic bacterial count in food after 24-48 hours.

Tempo TVC uses a vial with culture medium and a card with a system of tubes and microtubes, whose technical principle MPN (most probable number). In during incubation, mesophilic aerobic microorganisms present in the card reduce the substrate in the culture medium and favors the appearance of a fluorescent signal that is detected by the Tempo Reader.

Work-Tempo method are:

$>$ preparing dilutions ;

distribution in vials :

$>\quad$ inoculated medium homogeneity;

$>$ sealing cards ;

vials enrollment data from cards and evidence;

$>\quad$ incubation cards 22 to 24 hours at $37^{\circ} \mathrm{C}$;

$>\quad$ reading and interpreting the results of the analysis concurrently with the issue .

The advantage of this method is the timeliness of the results of the TNGMA, the total time of the analysis method being 24 hours.

\section{RESULTS AND DISCUSSION}

\section{The results of chemical analysis}

Analysis of the chemical composition of the eggs from the determinations carried out on 90 eggs is shown in Table 1.

Table 1 The chemical composition of eggs from the two systems agreed EU (g/100 g dry weight)

\begin{tabular}{|c|c|c|c|c|}
\hline Egg Components & $\begin{array}{l}\text { Chemical } \\
\text { Components (\%) }\end{array}$ & $\begin{array}{l}\text { Statistical } \\
\text { Estimators }\end{array}$ & $\begin{array}{l}\text { Batch A } \\
\text { Free range }(n=15)\end{array}$ & $\begin{array}{l}\text { Batch B } \\
\text { Approved } \\
\text { Batteries }(n=15)\end{array}$ \\
\hline \multirow{18}{*}{ Albumen } & \multirow{3}{*}{ Water } & $\bar{X} \pm \mathrm{s} \bar{x}$ & $87.883 \pm 0.02$ & $88.000 \pm 0.00$ \\
\hline & & $\mathrm{V} \%$ & 0.09 & 0.01 \\
\hline & & Fisher Test & $\hat{\mathrm{F}}=34.73>\mathrm{F}_{0.001}=13.497 \rightarrow * * *$ & \\
\hline & \multirow{3}{*}{$\begin{array}{l}\text { Dry } \\
\text { matter }\end{array}$} & $\overline{\bar{X}} \pm \mathrm{s} \bar{x}$ & $12.117 \pm 0.02$ & $12.000 \pm 0.00$ \\
\hline & & $\mathrm{V} \%$ & 0.63 & 0.09 \\
\hline & & Fisher Test & $\hat{\mathrm{F}}=34.73>\mathrm{F}_{0.001}=13.497 \rightarrow * * *$ & \\
\hline & \multirow{3}{*}{ Proteins } & $\bar{X} \pm \mathrm{s} \bar{x}$ & $10.360 \pm 0.12$ & $9.980 \pm 0.03$ \\
\hline & & $\mathrm{V} \%$ & 1.97 & 0.49 \\
\hline & & Fisher Test & $\hat{\mathrm{F}}=48.03>\mathrm{F}_{0.001}=13.497 \rightarrow * * *$ & \\
\hline & \multirow{3}{*}{ Lipids } & $\overline{\bar{X}} \pm \mathrm{s} \bar{x}$ & $0.063 \pm 0.00$ & $0.071 \pm 0.00$ \\
\hline & & $\mathrm{V} \%$ & 23.62 & 19.01 \\
\hline & & Fisher Test & $\hat{\mathrm{F}}=2.35<\mathrm{F}_{0.05}=4.195 \rightarrow$ n.s. & \\
\hline & \multirow{3}{*}{ Ash } & $\bar{X} \pm \mathrm{s} \bar{x}$ & $0.819 \pm 0.01$ & $0.862 \pm 0.01$ \\
\hline & & $\mathrm{V} \%$ & 3.02 & 3.29 \\
\hline & & Fisher Test & $\hat{\mathrm{F}}=19.90>\mathrm{F}_{0.001}=13.497 \rightarrow * * *$ & \\
\hline & \multirow{3}{*}{ Nitrogen free extract } & $\bar{X} \pm \mathrm{s} \bar{x}$ & $0.885 \pm 0.06$ & $1.093 \pm 0.02$ \\
\hline & & $\mathrm{V} \%$ & 26.73 & 5.95 \\
\hline & & Fisher Test & $\hat{\mathrm{F}}=10.71<\mathrm{F}_{0.001}=13.497 \rightarrow * * *$ & \\
\hline \multirow{15}{*}{ Yolk } & \multirow{3}{*}{ Water } & $\bar{X} \pm \mathrm{s} \bar{x}$ & $49.447 \pm 0.01$ & $49.237 \pm 0.24$ \\
\hline & & $\mathrm{V} \%$ & 0.07 & 1.87 \\
\hline & & Fisher Test & $\hat{\mathrm{F}}=0.77<\mathrm{F}_{0.05}=4.196 \rightarrow$ n.s. & \\
\hline & \multirow{3}{*}{ Dry matter } & $\bar{X}_{ \pm \mathrm{S}} \bar{x}$ & $50.553 \pm 0.01$ & $50.763 \pm 0.24$ \\
\hline & & $\mathrm{V} \%$ & 0.06 & 1.81 \\
\hline & & Fisher Test & $\hat{\mathrm{F}}=0.77<\mathrm{F}_{0.05}=4.195 \rightarrow$ n.s. & \\
\hline & \multirow{3}{*}{ Proteins } & $\bar{X} \pm \mathrm{S} \bar{x}$ & $17.449 \pm 0.00$ & $17.190 \pm 0.00$ \\
\hline & & $\mathrm{V} \%$ & 0.10 & 0.08 \\
\hline & & Fisher Test & $\hat{\mathrm{F}}=2048.83>\mathrm{F}_{0.001}=13.497 \rightarrow * * *$ & \\
\hline & \multirow{3}{*}{ Lipids } & $\bar{X} \pm \mathrm{s} \bar{x}$ & $30.114 \pm 0.02$ & $29.439 \pm 0.04$ \\
\hline & & $\mathrm{V} \%$ & 0.26 & 0.51 \\
\hline & & Fisher Test & $\hat{\mathrm{F}}=235.05>\mathrm{F}_{0.001}=13.497 \rightarrow * * *$ & \\
\hline & \multirow{3}{*}{ Ash } & $\bar{X} \pm \mathrm{s} \bar{x}$ & $1.801 \pm 0.01$ & $1.783 \pm 0.00$ \\
\hline & & $\mathrm{V} \%$ & 1.73 & 0.72 \\
\hline & & Fisher Test & $\hat{\mathrm{F}}=4.61<\mathrm{F}_{0.01}=7.635 \rightarrow * *$ & \\
\hline
\end{tabular}




\begin{tabular}{|c|c|c|c|c|}
\hline & \multirow{3}{*}{ Nitrogen free extract } & $\bar{X} \pm \mathrm{s} \bar{x}$ & $1.189 \pm 0.02$ & $2.347 \pm 0.24$ \\
\hline & & $\mathrm{V} \%$ & 5.52 & 39.37 \\
\hline & & Fisher Test & \multicolumn{2}{|l|}{$\hat{\mathrm{F}}=23.45>\mathrm{F}_{0.001}=13.497 \rightarrow * * *$} \\
\hline \multirow{18}{*}{ Melange } & \multirow{3}{*}{ Water } & $\bar{X} \pm \mathrm{s} \bar{x}$ & $76.614 \pm 0.01$ & $77.031 \pm 0.01$ \\
\hline & & $\mathrm{V} \%$ & 0.07 & 0.05 \\
\hline & & Fisher Test & $\hat{\mathrm{F}}=591.34>\mathrm{F}_{0.001}=13.497 \rightarrow * * *$ & \\
\hline & \multirow{3}{*}{$\begin{array}{l}\text { Dry } \\
\text { matter }\end{array}$} & $\bar{X} \pm \mathrm{s} \bar{x}$ & $23.386 \pm 0.01$ & $22.969 \pm 0.01$ \\
\hline & & $\mathrm{V} \%$ & 0.24 & 0.16 \\
\hline & & Fisher Test & $\hat{\mathrm{F}}=591.34>\mathrm{F}_{0.001}=13.497 \rightarrow * * *$ & \\
\hline & \multirow{3}{*}{ Proteins } & $\overline{\bar{X}} \pm \mathrm{s} \bar{x}$ & $12.953 \pm 0.01$ & $12.517 \pm 0.01$ \\
\hline & & $\mathrm{V} \%$ & 0.24 & 0.19 \\
\hline & & Fisher Test & $\hat{\mathrm{F}}=1882.86>\mathrm{F}_{0.001}=13.497 \rightarrow * * *$ & \\
\hline & \multirow{3}{*}{ Lipids } & $\overline{\bar{X}} \pm \mathrm{s} \bar{x}$ & $7.665 \pm 0.01$ & $7.397 \pm 0.01$ \\
\hline & & $\mathrm{V} \%$ & 0.63 & 0.30 \\
\hline & & Fisher Test & $\hat{\mathrm{F}}=379.86>\mathrm{F}_{0.001}=13.497 \rightarrow * * *$ & \\
\hline & \multirow{3}{*}{ Ash } & $\bar{X} \pm \mathrm{s} \bar{x}$ & $0.862 \pm 0.01$ & $0.881 \pm 0.00$ \\
\hline & & $\mathrm{V} \%$ & 4.04 & 2.10 \\
\hline & & Fisher Test & $\hat{\mathrm{F}}=5.60<\mathrm{F}_{0.01}=7.635 \rightarrow * *$ & \\
\hline & \multirow{3}{*}{ Nitrogen free extract } & $\bar{X} \pm \mathrm{s} \bar{x}$ & $1.906 \pm 0.02$ & $2.175 \pm 0.02$ \\
\hline & & $\mathrm{V} \%$ & 4.04 & 3.12 \\
\hline & & Fisher Test & $\hat{\mathrm{F}}=102.88>\mathrm{F}_{0.001}=13.497 \rightarrow * * *$ & \\
\hline
\end{tabular}

The results of analysis performed on whites of eggs from hens reared free range system showed higher values of dry matter $(12.11 \pm 0.02$ vs. $12.00 \pm 0.00)$. If analyzed water content feature presented a very good homogeneity (V\% $=0.01$ to 0.09). The chemical indicators track all results for albumen were very significant, except lipids, where they were insignificant. Research conducted on yolk showed that eggs from free range systems have higher values in most chemical indicators: the lipids content of $30.11 \pm 0.02 \%$ compared to eggs from hens exploited in approved battery system where the value was $29.44 \pm 0.04 \%$, the nitrogen free extract, was lower in eggs from alternative systems (1.18 \pm 0.02 vs. $2.34 \pm 0.24)$. The analysis of mean values was observed that the amount of mix dry matter was higher in the range $23.38 \pm 0.01 \%$ free system compared to the conventional system where there was $22.96 \pm 0.01 \%$. Interval limits were found lower than the ranges found in other studies $23.50 \%-31.31 \%$ (Galis $\boldsymbol{e t}$. al., 2012, Hidalgo et al., 2008). In terms of protein content values recorded were higher than value found in the literature, for free range system were was registered $12.95 \pm 0.01 \%$ and $12.51 \pm 0.01 \%$ for the conventional system. The average values for the quantity of ash was observed that eggs from the free range system containing $0.86 \pm 0.01 \%$ and $0.88 \pm 0.00 \%$ for the approved baterry system; limits set by the literature were $0.84 \%$ - $1.12 \%$ (Galiș et al. 2012, Radu- Rusu et al. 2012).

Table 2 NTGMA Evolution of egg contents from EU approved systems (cfu /g)

\begin{tabular}{|c|c|c|c|c|}
\hline Specification & & $\mathrm{n}$ & $\bar{X}_{ \pm \mathrm{S}} \bar{x}$ & $\mathrm{~V} \%$ \\
\hline \multirow{2}{*}{$\begin{array}{l}\text { TNGMA } \\
7 \text { days } \\
\end{array}$} & Batch A & 5 & $2.150 \pm 0.18$ & 8.35 \\
\hline & Batch B & 5 & $1.773 \pm 0.51$ & 28.68 \\
\hline \multicolumn{2}{|l|}{ Fisher Test } & & \multicolumn{2}{|c|}{$\hat{\mathrm{F}}=\mathbf{2 . 0 6 9}<\mathrm{F}$ 0.05 .5.317 $\rightarrow$ n.s } \\
\hline \multirow{2}{*}{$\begin{array}{l}\text { TNGMA } \\
14 \text { days }\end{array}$} & Batch A & 5 & $2.400 \pm 0.42$ & 17.36 \\
\hline & Batch B & 5 & $2.273 \pm 0.53$ & 23.19 \\
\hline Fisher Test & & & \multicolumn{2}{|c|}{$\hat{\mathrm{F}}=0.228<\mathrm{F} 0.055 .317 \rightarrow$ n.s. } \\
\hline \multirow{2}{*}{$\begin{array}{l}\text { TNGMA } \\
21 \text { days } \\
\end{array}$} & Batch A & 5 & $2.765 \pm 0.58$ & 21.01 \\
\hline & Batch B & 5 & $2.298 \pm 0.21$ & 8.97 \\
\hline Fisher Test & & & \multicolumn{2}{|c|}{$\hat{\mathrm{F}}=5.312<$ F $0.05 \quad 5.317 \rightarrow$ n.s. } \\
\hline
\end{tabular}

\section{The results of microbiological analysis}

Microbiological analysis performed in the 3 stages of the storage, showed a higher microbial load for eggs from free range system; so that the 7 days of storage at $+4^{\circ} \mathrm{C}$ and relative humidity of $90 \%$ for the egg content (melange) provided from the free range system occurred $2.15 \pm 0.18 \mathrm{cfu} / \mathrm{g}$ and at the eggs from approved battery has $1.77 \pm 0.51 \mathrm{ufc} / \mathrm{g}$. At the end of the validity period 21 days higher values $(2.76 \pm 0.58 \mathrm{ufc} / \mathrm{g}$ vs $2.29 \pm 0.21 \mathrm{cfu} / \mathrm{g})$, found in the free range system, compared with the agreed battery one may be due to microclimate factors, less salubrious contact spaces inside the hall and microbial load of the air in the halls free range as confirmed by the literature (Vučemilo et al., 2010) .
Table 3 NTGMA evolution of the mineral shell eggs from EU agreed systems (log cfu /eggshell)

\begin{tabular}{lllc}
\hline Specification & & $\mathrm{n}$ & $\log$ ufc/eggshell \\
\hline NTGMA & Batch A & 5 & 4.80 \\
\cline { 2 - 4 } 7 zile & Batch B & 5 & 4.77 \\
\hline NTGMA & Batch A & 5 & 4.87 \\
\cline { 2 - 4 } 14 zile & Batch B & 5 & 4.85 \\
\hline NTGMA & Batch A & 5 & 5.01 \\
\cline { 2 - 4 } 21 zile & Batch B & 5 & 4.95 \\
\hline
\end{tabular}

Regarding the bacterial contamination of mineral shell, the results show a higher rate of microorganisms present on the shell eggs from free range system both at 7 days of storage (4.80 log cfu/shell) unlike eggs produced in cages (4. $77 \mathrm{log}$ $\mathrm{cfu} / \mathrm{shell})$ and 21 days (5.01 $\log \mathrm{cfu} / \mathrm{shell}$ vs $4.95 \mathrm{log} \mathrm{cfu} / \mathrm{shell})$. From the analyzes carried out, the results are lower than the values recorded by De Reu K. et al. (2006), for free range system $5.46 \mathrm{log} \mathrm{cfu} / \mathrm{shell}$ and the approved battery highest value $5.06 \log \mathrm{cfu} / \mathrm{shell}$. 


\section{CONCLUSION}

The results showed differences between eggs analyze chemical cues taken from both conventional and free range systems.

Eggs obtained from free range system had a higher protein content both whites $(10.36 \%$ vs. $9.98 \%)$ and yolk $(17.44 \%$ vs. $17.19 \%)$ compared with the conventional system, a phenomenon which was due to the fact that birds reared free range system benefited from additional sources of food.

In terms of dry matter, it has been a qualitative improvement in free range system both for the white $(12.11 \%$ vs. $12.00 \%)$

Chemical analysis of studied eggs, for melange showed a higher rate of dry matter, protein and fat $7.66 \%$ vs. $7.39 \%$.

The microbiological determinations made, bacterial contamination was higher in eggs from free range system, unlike those from EU approved batteries operation sistem.

So if TNGMA determination of the content of eggs, free range system at the end of the recommended stotage period ( 21 days) had a value of $2.76 \pm 0.58 \mathrm{cfu} / \mathrm{g}$ versus $0.21 \pm 2.29 \mathrm{cfu} / \mathrm{g}$ registered at eggs from agreed battery.

Regarding the microbial load of the mineral shell that it is higher in eggs from alternative systems for our free range system $5.01 \mathrm{log}$ cfu/shell, unlike battery which is $4.95 \log \mathrm{cfu} / \mathrm{shell}$.

Alternative systems of breeding offers laying hens significant advantages in terms of animal welfare, ethological and in terms of nutritional quality of eggs, but not in terms of hygiene and food safety .

Acknowledgments: This paper was published under the frame of European Social Fund. Human Resources Development Operational Programme 2007 2013, project no. POSDRU/159/1.5/S/132765.

\section{REFERENCES}

ANDERSON, K. E. 2009 - Overview of natural and organic production: Looking back to the future, J. Appl. Poultry Research. 18:348-354. http://dx.doi.org/10.3382/japr.2008-00119.

DE REU, K., GRIJSPEERDT, K., HEYNDRICKX, M., UYTTENDAELE, M. DEBEVERE, J., HERMAN, L. 2006 - Bacterial shell contamination in the egg collection chains of different housing systems for laying hens. British Poultry Science 17 (2), 163-172. http://dx.doi.org/10.1080/00071660600610773.

GALIȘ, ANCA-MARIA, VAN, I., THÉWIS A. 2012 - Organoleptic chemical and microbiological quality of table eggs obtained in different exploitation systems for laying hens in Romania, Scientific Papers, Animal Science, Series D, vol. LV CD-ROM ISSN 2285-5769, ISSN-L 2285-5750.

HIDALGO, A., ROSSI, M., CLERICI, F., RATTI, S. 2008.- A market study on the quality characteristics of eggs in different housing system. Food Chemistry, 106:1031:1038, http://dx.doi.org/10.1016/i.foodchem.2007.07.019.

MATT D.,VEROMANN E., LUIK A., 2009 - Effect of housing system on biochemical composition of chicken eggs, Agronomy Research, 7 (Special Issue II), 662 - 667.

MINELli, G., SIRRI. F., FOLEGATTI. E., MELUZZI. A., FRANCHINI, A. 2007 - Egg quality traits of laying hens reared in organic and conventional systems, Ital. J. Anim. Sci. 58, 518 - 528 http://dx.doi.org/10.4081/ijas.2007.1s.728.

RADU - RUSU, R.M., USTUROI, M.G., RADU- RUSU, CRISTINA, VACARU - OPRIȘ, I. 2012 - Nutritional peculiarities of the hen eggs produced within improved cages or free range alternative systems, Lucrări științifice Seria Zootehnie, vol 57.

USTUROI, M. G. 2004 - Production of eggs for consumption, Editura „Ion Ionescu de la Brad", Iași.

VUČEMILO, M., VINKOVIC, B., MATKOVIC, K., STOKOVIC, I., JAKSIC, S., RADOVIC, S., GRANIC K., STUBICAN, D. 2010 - The influence of housing systems on the air quality and bacterial eggshell contamination of table eggs. Czech Journal of Animal Science. 55 (6) 243-249.

*** - A.O.A.C.. 1990 - Association of Official Analytical Chemists. Food Composition; Additives; Natural Contaminants. vol. II. Cap. 34 - Egg and eggs products.

***-SR EN ISO 5983-1:2006/AC:2009 Nutreţuri - Determination of nitrogen content and calculation of crude protein content . Part 1: Kjeldahl method .

***-SR EN ISO 4833:2003 Microbiology of food and animal feeding stuffs . Horizontal method for the enumeration of microorganisms. Colony-count technique at 30 degrees $\mathrm{C}$ 